\title{
Epidemiology and molecular characterization of hepatitis B virus in Luanda, Angola
}

\author{
Fatima Valente ${ }^{1,2}$, Barbara Vieira do Lago', Carlos Augusto Velasco de Castro ${ }^{3}$, \\ Adilson José de Almeida ${ }^{4}$, Selma A Gomes ${ }^{1}$, Caroline Cordeiro Soares ${ }^{1 /+}$ \\ 'Laboratório de Virologia Molecular ${ }^{3}$ Laboratório de AIDS e Imunologia Molecular, \\ Instituto Oswaldo Cruz-Fiocruz, Rio de Janeiro, RJ, Brasil \\ ${ }^{2}$ Fundação Eduardo dos Santos, Ministério da Saúde, Angola \\ ${ }^{4}$ Hospital Universitário Gaffrée e Guinle, Universidade Federal do Estado do Rio de Janeiro, Rio de Janeiro, RJ, Brasil
}

\begin{abstract}
An estimated 360 million people are infected with hepatitis B virus (HBV) worldwide. Among these, 65 million live in Africa. Despite the high levels of hepatitis B in Africa, HBV epidemiology is still poorly documented in most African countries. In this work, the epidemiological and molecular characteristics of HBV infection were evaluated among the staff, visitors and adult patients $(n=508)$ of a public hospital in Luanda, Angola. The overall prevalence of hepatitis B core antibody (anti-HBc) and hepatitis B surface antigen was $79.7 \%$ and $15.1 \%$, respectively. $H B V$ infection was higher in males and was more prevalent in individuals younger than 50 years old. HBV-DNA was detected in 100\% of HBV "e" antigen-positive serum samples and in 49\% of anti-hepatitis Be antibody-positive samples. Thirty-five out of the $40 \mathrm{HBV}$ genotypes belonged to genotype E. Circulation of genotypes A (4 samples) and D (1 sample) was also observed. The present study demonstrates that HBV infection is endemic in Luanda, which has a predominance of genotype E. This genotype is only sporadically found outside of Africa and is thought to have emerged in Africa at a time when the trans-Atlantic slave trade had stopped.
\end{abstract}

Key words: hepatitis B virus - HBV-DNA - genotypes - HIV-1

Hepatitis B virus (HBV) (family Hepadnaviridae, genus Orthohepadnavirus) is an etiologic agent of acute and chronic liver disease in humans. It is estimated that more than 2 billion people in the world have been infected with HBV. Of these, approximately 360 million are chronically infected and at risk of serious illness and death from cirrhosis and hepatocellular carcinoma (WHO 2004). At least 65 million of all chronically infected individuals live in Africa (WHO 2004, Kramvis \& Kew 2007). The prevalence of HBV surface antigen (HBsAg) has been reported to vary substantially among African countries from less than $5 \%$ to up to $15 \%$ (Sutcliffe et al. 2002, Msuya et al. 2006, Pirillo et al. 2007). Sub-Saharan Africa is a region where the prevalence of anti-HBV antibodies and HBsAg is very high (Pawlotsky et al. 1995, Kurbanov et al. 2005, Makuwa et al. 2006, Bekondi et al. 2007). Antibody to HBV core antibody (anti-HBc) prevalence in western Africa is estimated to be more than $85 \%$ (Kramvis \& Kew 2007). Regions of low, intermediate and high prevalence of HBsAg can also be found in Africa. Despite this high number, the epidemiological and molecular patterns of HBV are still poorly documented in some countries, including Angola.

Financial support: CNPq, FAPERJ

+Corresponding author: csoares@ioc.fiocruz.br

Received 18 May 2010

Accepted 12 August 2010
Angola is a country with an estimated population of 17 million and a total area of 1.24 million $\mathrm{km}^{2}$. Located on the west coast of Southern Africa, Angola is bordered by the Democratic Republic of Congo (formerly Zaire), Zambia and Namibia. Of the few studies that have been conducted in these countries, it has been suggested that Namibia is a region of high (18\%) HBsAg prevalence (Botha et al. 1984, Steele et al. 1995) Zambia and the Democratic Republic of Congo are of intermediary endemicity, with $6.5 \%$ and $5.4 \%$ HBsAg prevalence, respectively (Oshitani et al. 1995, André 2000, Batina et al. 2007). The results from the few previous studies conducted in Angola showed the presence of HBV in pregnant women with or without jaundice (Strand et al. 2003) and estimated the HBsAg prevalence to be $13 \%$ among patients and healthcare workers from a hospital in Mucusso, Angola (Steele \& Bos 1996).

HBV is classified into eight genotypes (A-H) that are related to their geographical origins. The genotypes are based on the greater than $8 \%$ sequence divergence that exists throughout the entire genome of the virus (Kramvis et al. 2005, Schaefer 2007). Most genotypes have been divided into subgenotypes with distinct virological and epidemiological properties. Recently, two new genotypes, designated I (Olinger et al. 2008) and J (Tatematsu et al. 2009), have also been proposed. In Africa, genotypes A, $\mathrm{D}$ and $\mathrm{E}$ are the most predominant. It is well established that genotype A is prevalent in Northwest Europe, Africa and the Americas. Genotype A, which circulates in Africa, was initially divided into two subgroups: A1 and A2. Subgroup A1 has been previously identified in three countries in sub-Saharan Africa, including South Africa, Zimbabwe and Malawi, which suggests that subgroup A1 
evolved within the indigenous populations of some African countries (Sugauchi et al. 2003). Studies of subgroup A2, classified as an "European" genotype, suggest that it may have been introduced to Europe by Portuguese traders who travelled through southern Africa during the XV century (Kramvis \& Kew 2007). Hannoun et al. (2005) have also speculated that the A2 subgenotype evolved from a subgroup of A1 isolates. A third subgenotype, named A3, was originally isolated in Cameroon (Kurbanov et al. 2005) and was subsequently identified in isolates from Gambia (Hannoun et al. 2005) and Mali (Olinger et al. 2006). The subgenotypes A4 and A5 were identified in Mali and Nigeria, respectively (Hannoun et al. 2005, Olinger et al. 2006). Currently, two new subgenotypes have been proposed, including A6, which was identified in patients from the Belgian Congo and Rwanda (Pourkarim et al. 2010), and A7, which was isolated in a subset of individuals from Cameroon (Hübschen et al). Genotype D is widespread, with a high prevalence in the Mediterranean and Middle East regions. At least seven subgenotypes within genotype D are known (designated D1-D7) (Meldal et al. 2009). Genotype D is the dominant genotype in northern Africa, with isolates clustering with subgenotype D1. South African isolates of genotype D clustered with subgenotype D3 (Kramvis \& Kew 2007). Genotype $\mathrm{E}$ is the most prevalent genotype in western and central Africa. Genotype E isolates have low genetic variability with unique features, such as an in-frame deletion of three nucleotides in the 5'-pre-S1 and, as deduced from the amino acid sequence of HBsAg, the rare serotype, ayw4. Another unique feature of genotype $\mathrm{E}$ isolates is a second start codon in the pre-S1 region (Kramvis \& Kew 2007). Due to its low genetic variability and the fact that this genotype is exclusively found in Africa or African descendants, Mulders et al. (2004) suggested that the introduction of genotype $\mathrm{E}$ into the human population is a more recent event that occurred from the mid to the late XIX century, at a time when the slave trade was already over.

The aim of the present study was to determine the prevalence and risk factors associated with HBV infection among staff, visitors and patients of a public hospital in Luanda, Angola, and to assess the HBV genotypes of these individuals.

\section{PATIENTS, MATERIALS AND METHODS}

Study population - Five hundred and eight individuals, including staff, visitors and patients of the Divine Providence Hospital in Luanda, were investigated. The population ranged from 18-76 years of age. Three hundred and twenty-six individuals were female and 182 were male. Informed consent was obtained from all participants. The individuals were asked about their socio-demographic characteristics (age, ethnicity, place of birth, schooling, occupation, marital status and the number of people living in the same house), exposure to risk factors linked to blood transmission, such as surgery, circumcision, organ transplant, blood transfusions, tattoos, body piercing/earrings or sharing of personal tools, family history or selfinfected by HBV. Volunteers were also asked about their sexual behavior, including sexual orientation, number of sexual partners and condom use and their histories of sexually transmitted diseases. Information about the human immunodeficiency virus (HIV) status, use of drugs for HIV therapies, HBV vaccination and use of injected drugs for each of the individuals was also collected.

Although the study was conducted at a hospital in Luanda, only $33.4 \%$ of the individuals were born in Luanda and $66.1 \%$ were born in other Angolan provinces. Blood samples and sera were collected and stored at $-20^{\circ} \mathrm{C}$ until use. The protocol used in this study was approved by the Ethical Committee of Oswaldo Cruz Foundation and by the Ethical Committee of the Republic of Angola.

Serological tests - Serum samples were screened by commercial enzyme linked immunosorbent assay (ELISA) for the presence of HBsAg (Biokit, Barcelona, Spain), anti-HBc, anti-HBc IgM and HBV surface antibody (antiHBs) (Diasorin, Sallugia, Italy). HBsAg-positive samples were also tested for the presence of HBV "e" antigen ( $\mathrm{HBeAg}$ ) and anti-hepatitis Be antibody (anti-Hbe) (Diasorin, Sallugia, Italy). These samples were also investigated for the presence of antibodies against HIV using the Vironostika HIV Uni-Form II Plus O (bioMérieux, Marcy l'Etoile, France). This commercial ELISA is useful for detecting antibodies against HIV-I, II and group O.

HBV-DNA detection and genotyping - Total nucleic acids were extracted from HBsAg-positive samples using the High Pure Viral Nucleic Acid kit (Roche Applied Science, Mannheim, Germany) following the manufacturer's instructions. HBV-DNA detection was performed by amplification of the pre-S/S region of the genome using a semi-nested polymerase chain reaction (PCR) assay. The first round of PCR was performed with $1 \mu \mathrm{L}$ of DNA and $1 \mathrm{U}$ of Taq DNA polymerase (Invitrogen, Carlsbad, San Diego, CA) in a final volume of $25 \mu \mathrm{L}$. The primers used to amplify the pre-S/S region of HBV were PS1 (5'-CCATATTCTTGGGAACAAGA-3', nucleotide position 2826-2845) andP3 (5'-AAAGCCCAAAAGACCCACAA-3', nucleotide position 1019-1000), for the first round, and PS1 and S2 (S2, 5'-GGGTTTAAATGTATACCCAAAA-3', nucleotide position 819-841), for the second round. After an initial denaturation step $\left(3 \mathrm{~min}\right.$ at $\left.94^{\circ} \mathrm{C}\right)$, DNA was amplified using 30 cycles at $95^{\circ} \mathrm{C}$ for $30 \mathrm{~s}, 52^{\circ} \mathrm{C}$ for $40 \mathrm{~s}$ and $72^{\circ} \mathrm{C}$ for $2 \mathrm{~min}$, followed by a final extension of $72^{\circ} \mathrm{C}$ for $7 \mathrm{~min}$. The second round of amplification was performed with $1 \mu \mathrm{L}$ of the PCR product from the first round of amplification along with sense primer PS1 and antisense primer S2 in a final volume of $50 \mu \mathrm{L}$ under the same conditions used for the first round. This two-round PCR assay has been used in several other studies (Niel et al. 1994, Araujo et al. 2004) and it has the sensitivity to detect approximately 30 DNA molecules. PCR products were loaded on $1.5 \%$ agarose gels, separated by electrophoresis, stained with ethidium bromideand visualized underUV light. Genotyping was performed by restriction fragment length polymorphism (RFLP) analysis as previously described (Araujo et al. 2004) using $10 \mu \mathrm{L}$ of PCR products digested separately with two units each of BamHI, EcoRI and StuI restriction endonucleases (Roche Molecular Biochemicals, Mannheim, Germany) at $37^{\circ} \mathrm{C}$ for $2 \mathrm{~h}$. Digested products were analyzed by electrophoresis in $2 \%$ agarose gels. The RFLP patterns were used for genotyping. 
$H B V$ sequencing - $\mathrm{PCR}$ products from pre-S/S regions were loaded onto $2 \%$ agarose gels and DNA bands were extracted from the agarose gels. Nucleotide sequences from these regions were determined by direct sequencing using the BigDye Terminator kit (Applied Biosystems, Foster City, CA, USA) with specific, internal HBV primers. Sequencing reactions were analyzed on an ABI373 automated sequencer (Applied Biosystems). Bioinformatics analyses of the sequences were performed using the Molecular Evolutionary Genetics Analysis software, version 4 (Tamura et al. 2007). Phylogenetics analyses were performed by comparing the sequences that were obtained in this study with international sequences that are representative of other genotypes, including specific African sequences.

Statistical analyses - A bivariate analysis was performed using the Chi-square $\left(\chi^{2}\right)$ test for independence with Yate's continuity correction and $\chi^{2}$ for trends when appropriate to compare proportions. A two-tailed $\mathrm{p}$ value $<0.05$ was considered statistically significant. All calculations, including multiple logistic regression analysis, were performed with the Statistical Package for the Social Sciences (SPSS for Windows, release 12.0; SPSS, Inc, Chicago, IL, USA).

\section{RESULTS}

Epidemiology of HBV - Among the 508 individuals that were investigated for HBV epidemiological risk factors and serological markers, $182(35.8 \%)$ were male and $326(64.2 \%)$ were female. The median age of the participants was 34 years (range from 18-76 years). The overall anti- $\mathrm{HBc}$ prevalence was $79.7 \%(\mathrm{n}=405)$, indicating that a high proportion of the population had been previously exposed to HBV. HBsAg/anti-HBc serological markers were found in 77 (15.1\%) subjects [38 male (M), 39 female (F)]. The anti-HBs/anti-HBc-positive serological pattern, corresponding to a resolved past HBV infection, was observed in $233(45.8 \%)$ individuals $(77 \mathrm{M}, 156 \mathrm{~F})$. As much as $6.3 \%$ of the population, which corresponds to 25 out of the 77 (32\%) HBsAg-positive individuals, simultaneously showed $\mathrm{HBsAg}$, anti-HBs and anti-HBc markers. All HBsAg-positive samples were negative for anti-HBc IgM. Twenty-two (4.3\%) individuals (8 M, 14 F) were positive for anti-HBs only, a serological pattern associated with a previous HBV vaccination, although only eight people declared that they had been vaccinated against HBV. This suggests that most of these individuals were positive for anti-HBs with undetectable levels of anti-HBc. One hundred and twenty-eight (14.8\%) individuals $(52 \mathrm{M}, 76 \mathrm{~F})$ were positive for anti-HBc alone and the remaining volunteers $(21 \mathrm{M}, 59 \mathrm{~F}, 15.7 \%$ of the total) had no HBV serological markers.

Several risk factors for HBV infection were evaluated (see Patients, Materials and Methods); however, only a few of them were significantly different between the HBV-infected and non-infected populations (Table). The seroprevalence of HBsAg was higher in men when compared to women $(21.4 \%$ vs. $11.6 \%, \mathrm{p}=0.0046)$. Previous self-history of hepatitis was significant for anti-HBc positivity $(\mathrm{p}=0.0465)$ and extremely significant $(\mathrm{p}=0.0004)$ for HBsAg positivity. The relationship of circumcision with HBV serological markers was evaluated only in men. Circumcision was significantly associated with anti-HBc positivity $(\mathrm{p}=0.004)$, but not with $\mathrm{HBsAg}$ positivity. Considering that only a few men (11/182) declared that they had earrings or piercings, this variable was analyzed only in women. No significant association was found between earrings or piercings and HBV markers.

TABLE

Epidemiological factors related to hepatitis B virus (HBV) core antibody (anti-HBc) and HBV surface antigen (HBsAg) positivity

\begin{tabular}{|c|c|c|c|c|c|}
\hline & \multirow{2}{*}{$\begin{array}{l}\text { Total group } \\
(\mathrm{n}=508) \\
\mathrm{n}(\%)\end{array}$} & \multicolumn{2}{|c|}{$\begin{array}{l}\text { Anti-HBc positivity } \\
\qquad(\mathrm{n}=405)\end{array}$} & \multicolumn{2}{|c|}{$\begin{array}{l}\text { HBsAg positivity } \\
\qquad(\mathrm{n}=77)\end{array}$} \\
\hline & & n $(\%)$ & $\mathrm{p}$ value & n $(\%)$ & $\mathrm{p}$ value \\
\hline Gender & & & 0.0885 & & 0.0049 \\
\hline Male & $182(35.8)$ & $153(84.1)$ & & $39(21.4)$ & \\
\hline Female & $326(64.2)$ & $252(77.3)$ & & $38(11.6)$ & \\
\hline Surgery history & & & 0.9281 & & 0.4757 \\
\hline No & $416(81.9)$ & $332(79.8)$ & & $61(14.7)$ & \\
\hline Yes & $81(15.9)$ & $65(80.2)$ & & $15(18.5)$ & \\
\hline NR & $11(2.2)$ & $8(72.7)$ & & $1(9.1)$ & \\
\hline Circumcision history in men & & & 0.004 & & 0.927 \\
\hline No & $43(23.6)$ & $29(67.4)$ & & $9(20.9)$ & \\
\hline Yes & $139(76.4)$ & $122(87.8)$ & & $30(21.6)$ & \\
\hline Family history of hepatitis & & & 0.9346 & & 0.2743 \\
\hline No & $366(72.1)$ & $292(79.8)$ & & $50(13.7)$ & \\
\hline Yes & $102(20.1)$ & $81(79.4)$ & & $19(18.6)$ & \\
\hline NR & $40(7.8)$ & $32(80)$ & & $8(20)$ & \\
\hline
\end{tabular}




\begin{tabular}{|c|c|c|c|c|c|}
\hline \multirow{3}{*}{ Previous self-history of hepatitis } & \multirow{2}{*}{$\begin{array}{l}\text { Total group } \\
(\mathrm{n}=508) \\
\mathrm{n}(\%)\end{array}$} & \multicolumn{2}{|c|}{$\begin{array}{l}\text { Anti-HBc positivity } \\
\qquad(\mathrm{n}=405)\end{array}$} & \multicolumn{2}{|c|}{$\begin{array}{l}\text { HBsAg positivity } \\
\qquad(\mathrm{n}=77)\end{array}$} \\
\hline & & $\mathrm{n}(\%)$ & $\mathrm{p}$ value & $\mathrm{n}(\%)$ & $\mathrm{p}$ value \\
\hline & & & 0.0469 & & 0.0004 \\
\hline No & $439(86.4)$ & $343(78.1)$ & & $55(12.5)$ & \\
\hline Yes & $54(10.6)$ & $49(90.7)$ & & $17(31.5)$ & \\
\hline NR & $15(3)$ & $13(86.7)$ & & $5(33.3)$ & \\
\hline Transfusion history & & & 0.2247 & & 0.3881 \\
\hline No & $435(85.6)$ & $344(79.1)$ & & $64(14.7)$ & \\
\hline Yes & $66(13)$ & $57(86.4)$ & & $13(19.7)$ & \\
\hline NR & $7(1.4)$ & $4(57.1)$ & & $0(0)$ & \\
\hline Tattooing & & & 0.3385 & & 0.0554 \\
\hline No & $444(87.4)$ & $352(79.3)$ & & $63(14.2)$ & \\
\hline Yes & $56(11)$ & $48(85.7)$ & & $14(25)$ & \\
\hline NR & $8(1.6)$ & $5(62.5)$ & & $0(0)$ & \\
\hline Earrings/piercings in women & & & 0.168 & & 0.926 \\
\hline No & $27(8.3)$ & $18(66.7)$ & & $3(11.1)$ & \\
\hline Yes & $299(91.7)$ & $234(78.3)$ & & $35(11.7)$ & \\
\hline Sharing piercing-cutting objects & & & 0.2116 & & 0.7597 \\
\hline No & $382(75.2)$ & $299(78.3)$ & & $57(14.9)$ & \\
\hline Yes & $114(22.4)$ & $96(84.2)$ & & $19(16.7)$ & \\
\hline NR & $12(2.4)$ & $10(83.3)$ & & $1(8.3)$ & \\
\hline Biohazardous accidents & & & 0.0763 & & 0.0606 \\
\hline No & $385(75.8)$ & $300(77.9)$ & & $51(13.2)$ & \\
\hline Yes & $109(21.4)$ & $94(86.2)$ & & $23(21.1)$ & \\
\hline NR & $14(2.8)$ & $11(78.6)$ & & $3(21.4)$ & \\
\hline Sexual activity & & & 0.1141 & & 0.1100 \\
\hline No & $39(7.7)$ & $27(69.2)$ & & $2(5.1)$ & \\
\hline Yes & $466(91.7)$ & $378(81.1)$ & & $75(16.1)$ & \\
\hline NR & $3(0.6)$ & $0(0)$ & & $0(0)$ & \\
\hline Past multiple sexual partners & & & 0.8332 & & 0.5693 \\
\hline No & $330(65)$ & $272(82.4)$ & & $47(14.2)$ & \\
\hline Yes & $61(12)$ & $49(80.3)$ & & $11(18)$ & \\
\hline NR & $117(23)$ & $84(71.8)$ & & $19(16.2)$ & \\
\hline Present multiple sexual partners & & & 0.2183 & & 0.5975 \\
\hline No & $443(87.2)$ & $349(78.8)$ & & $65(14.7)$ & \\
\hline Yes & $36(7.1)$ & $32(88.9)$ & & $7(19.4)$ & \\
\hline NR & $29(5.7)$ & $24(82.7)$ & & $5(17.2)$ & \\
\hline Condom use & & & 0.7309 & & 0.4440 \\
\hline No/ sporadically & $422(83.1)$ & $338(80.1)$ & & $65(15.4)$ & \\
\hline Always & $48(9.4)$ & $40(83.3)$ & & $10(20.8)$ & \\
\hline NR & $38(7.5)$ & $27(71)$ & & $2(5.3)$ & \\
\hline HIV coinfection & & & 0.2916 & & 0.3649 \\
\hline No & $401(78.9)$ & $315(78.5)$ & & $56(14)$ & \\
\hline Yes & $105(20.7)$ & $88(83.8)$ & & $19(18.1)$ & \\
\hline NR & $2(0.4)$ & $2(100)$ & & $2(100)$ & \\
\hline STD history & & & 0.3155 & & 0.9200 \\
\hline No & $271(53.5)$ & $211(77.8)$ & & $42(15.5)$ & \\
\hline Yes & $211(41.5)$ & $173(82)$ & & $32(15.2)$ & \\
\hline NR & $26(5)$ & $21(80.7)$ & & $3(11.5)$ & \\
\hline Previous HBV vaccination & & & 0.0952 & & 0.8285 \\
\hline No & $491(96.6)$ & $394(80.2)$ & & 75 (15.3) & \\
\hline Yes & $8(1.6)$ & $4(50)$ & & $1(12.5)$ & \\
\hline NR & $9(1.8)$ & $7(77.8)$ & & 1 (11.1) & \\
\hline
\end{tabular}

HIV: human immunodeficiency virus; NR: not reported; STD: sexually transmitted diseases. Missing values were not included in the statistical analysis. $\mathrm{p}<0.05$ (in bold) are statistically significant. 
There were no significant differences in HBsAg prevalence among adults between age groups younger than 50 years $(17.6 \%, 15.1 \%$ and $17.2 \%$ in age groups of 18 29, 30-39 and 40-49, respectively); however, the HBsAg prevalence decreased to $6.9 \%$ in people over 50 years old. HBsAg is more prevalent in men of all age groups (Fig. 1A). Most (71.4\%) HBsAg-positive samples were antiHBe positive. HBeAg was found in $18.2 \%$ of men and the remaining $10.4 \%$ were either positive (4 samples) or negative (4 samples) for both HBeAg and anti-HBe.

$H B V / H I V$ co-infection - Among the studied population, $210(42 \%)$ individuals declared that they have had an HIV detection test and 72 of these individuals declared that they were HIV positive (all 72 individuals were in treatment for HIV/AIDS at the hospital). The entire study population was also tested in our laboratory for HIV seropositivity, confirming anti-HIV in these 72 people and in 33 more individuals. HIV prevalence was highest in adults aged 30-39 years old (30.3\%) and lowest in people older than 50 years of age (11.1\%). Fig. 1B shows that the highest prevalence of HIV in women was in the individuals aged 30-39 years old (33.6\%) (30-39 years old) while in men it was in the 40-49 years old group $(26.9 \%)$. Co-infection with HBV was found in $18 \%(19 / 105)$ of the HIV-positive population.

$H B V-D N A$ detection and genotypes - HBV-DNA was detected in 41 out of 77 (53\%) of HBsAg-positive samples, without significant difference depending on their antiHBs status $(13 / 25,52 \%$ among anti-HBs positive people and 28/52, 54\% among anti-HBs negative individuals).
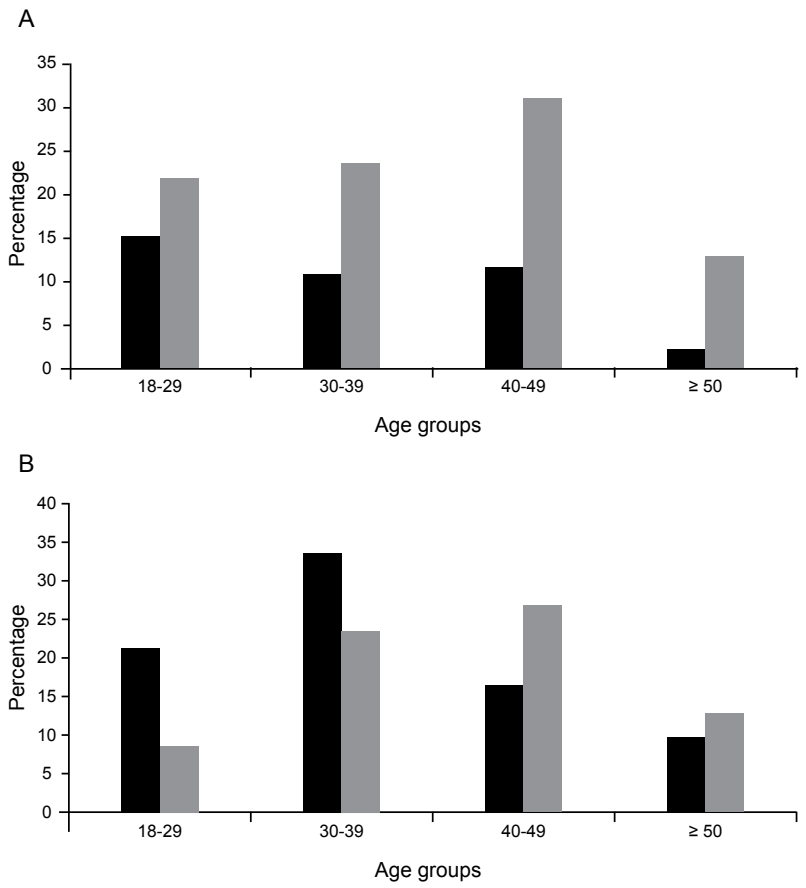

Fig. 1A: prevalence of hepatitis B virus surface antigen according to gender and age (black columns: female gender; white columns: male gender); B: prevalence of anti-human immunodeficiency virus by gender and age (black columns: female gender; white columns: male gender).
All 14 (100\%) HBeAg-positive/anti-HBe-negative samples were HBV-DNA positive. Among HBeAg-negative/ anti-HBe positive samples, 27/55 (49\%) were HBV-DNA positive. Pre-S/S PCR-RFLP analysis permitted the detection of HBV genotypes in 40 out of the 41 HBV-DNApositive samples. Thirty-five samples belonged to genotype $\mathrm{E}$, four belonged to genotype $\mathrm{A}$ and one belonged to genotype D. Fifteen samples (10 genotype E, 4 genotype $A$ and 1 genotype D) that were genotyped by PCR-RFLP were also submitted to nucleotide sequencing. Phyloge-

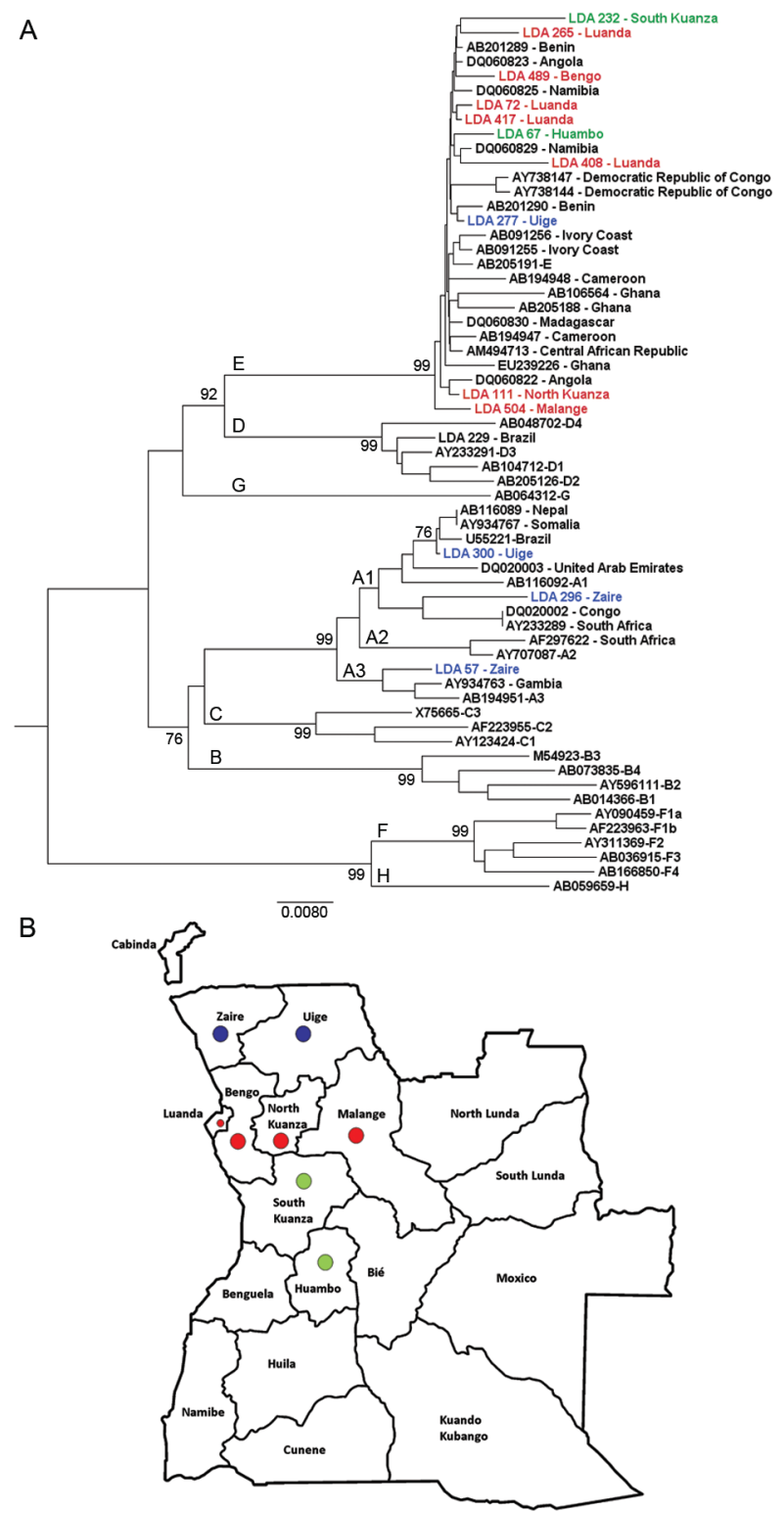

Fig. 2A: phylogenetic tree of pre-S/S nucleotide sequences. Sequences from this work are displayed in red (derived from individuals whose birth places were at same latitude of Luanda), blue (north of Luanda) and green (south of Luanda). Sequences obtained in this study are available on GenBank under accession from HM195104-HM195118; B: Lower part: map from Angolan provinces. Circles represent birth places of individuals whose hepatitis B virus isolates were genotyped (color codes as described above). 
netics analyses (Fig. 2) confirmed the results of all RFLP genotypes and showed that genotype $\mathrm{E}$ isolates from Angola (sequences named by their LDA numbers followed by birth places) did not cluster separately from those within Africa. Among the four genotype A isolates, two clustered within subgenotype A1 (LDA 296-Zaire and LDA300-Uíge) and one clustered within subgenotype A3 (LDA 57-Zaire). The last sample from genotype A, LDA 495-Luanda, clustered within subgenotype A2 (the phylogeny was obtained by alignment of the $\mathrm{S}$ region because the pre-S/S region of this sample was not able to be amplified by PCR; data not shown). Interestingly, subgenotypes $\mathrm{A} 1$ and $\mathrm{A} 3$ were derived from people who were born to the north of Luanda (Fig. 2).

\section{DISCUSSION}

Despite the high endemicity of HBV infection in sub-Saharan Africa, little is known about HBV seroepidemiology and genotype distribution in many African countries, such as Angola. The only previously published study of our knowledge about HBV epidemiology, conducted more than 10 years ago in Angola (Steele \& Bos 1996), showed a high (79\%) prevalence of HBV. The present study confirmed that extremely high HBV rates exist in Angola because $79.7 \%$ of the studied population was anti-HBc positive, which indicates previous contact with the virus, and $15.1 \%$ of the individuals were carriers of HBsAg, which is a marker of active HBV infection. Despite the burden of hepatitis B in Angola, only a few individuals declared that they had been vaccinated against HBV. Our data show that Luanda is a hyperendemic area for HBV infection and emphasizes the need for HBV prevention programs for adults to reduce the spread of this important human pathogen. It is known that $\mathrm{HBeAg}$ levels may vary greatly from one African population to another (Kramvis \& Kew 2007). In our study, the levels of $\mathrm{HBeAg}(18.2 \%)$ were similar to those found in adults in Benin (19\%) and slightly lower than those found in adults in Ethiopia (23\%) and Zimbabwe (25\%). Yet, HBeAg levels found in Luanda were much higher than those recorded in other African countries, such as the Central African Republic (4.5\%) and Nigeria (2.3\%) (Kramvis \& Kew 2007).

Risk factors for HBV infection may vary considerably depending on epidemiological data, the geographic region and the social, cultural and demographic characteristics of different populations. Some predisposing risk factors have been associated with HBV infection in different African populations, such as unprotected sexual activities (Abou et al. 2009), multiple sexual partners and blood transfusions (Adoga et al. 2009). In this cohort of Angolans, HBV infection was not associated with the most common predisposing risk factors, which is probably due to the very high rate of HBV infection in this cohort (about 80\%). The knowledge of a past hepatitis infection was the only statistically significant factor associated with both anti-HBc and HBsAg markers.

Differences in HBsAg rates between genders were found in some populations, but not in others (Kramvis \& Kew 2007). In our study, HBsAg prevalence was higher in men than in women $(\mathrm{p}=0.0049)$.
In sub-Saharan Africa, the predominant HBV transmission route is horizontal, mostly due to children being infected during early childhood (under 5 years of age) (Kew 1996, Martinson et al. 1998, Dumpis et al. 2001). Perinatal transmission seems to play a minor role in Africa, which is in contrast to what is observed in other high-prevalence endemic areas, such as southeast Asia, where materno-fetal transmission is the dominant route of transmission (Zhang et al. 1998). In low-endemic countries, such as western Europe, sexual transmission and high-risk behavior represent major factors (François et al. 2008). Here, no significant differences in HBsAg prevalence were found between adults in the range of 18-49 years old. Individuals younger than 18 years old were not analyzed. Consequently, it was not possible to determine which route of transmission is more important: horizontal-childhood transmission or sexual transmission. Considering that Angola is a hyperendemic area for HBV infection, it is possible that a higher rate of transmission occurs during childhood than in adulthood.

Studies conducted in Africa showed that rates of HBV co-infection among HIV-positive individuals vary from $6.1 \%$ in Kenya (Harania et al. 2008) to $25.9 \%$ in Nigeria (Uneke et al. 2005). Among the individuals from Divine Providence Hospital, $18 \%$ of HIV patients were co-infected with HBV. Despite HBV and HIV sharing common routes of transmission (parenteral and sexual), our data suggest that the two viruses were differentially transmitted and/or maintained between genders and age groups. Indeed, HBV infection was more prevalent in men than in women in all age groups while HIV showed a different pattern depending on age. In younger people, HIV was more prevalent in women, while in older people, HIV was more prevalent in men (Fig. 1B).

In this study, HBV DNA was detected in $53 \%$ of the HBsAg-positive samples. This rate was lower than the $84 \%$ obtained in previous studies with HBsAg-positive samples from Brazilian patients using the same method (Araujo et al. 2004) and the $98 \%$ obtained with other methods (real time PCR, transcription-mediated amplification) among HBsAg-positive samples from Ghana, a country where genotype $\mathrm{E}$ is circulating (Allain et al. 2003). Differences in methodologies, HBeAg positivity rates and/or viral loads may account for these differences.

HBV genotype E was the most prevalent genotype, which was found in $87.5 \%(35 / 40)$ of the genotyped samples, followed by genotype A, which was found in $10 \%$ $(4 / 40)$ of samples. Genotype D is the dominant genotype in northern Africa; however, it was identified in only one sample, which was derived from a Brazilian woman who works at the Divine Providence Hospital (Fig. 2). It was not possible to determine the place of origin of this isolate because genotype $\mathrm{D}$ was found to be predominant in the Brazilian population (Araujo et al. 2004, Mello et al. 2007). Genotype E is thought to be the most recent genotype originating in Africa. It is exclusively found in Africa or in African descendants living worldwide (Bekondi et al. 2007, Kramvis \& Kew 2007, Palumbo et al. 2007, Sitnik et al. 2007). Within Africa, it has a higher prevalence in Western African countries, including Senegal, Cote d'Ivoire, Ghana, Nigeria and Namibia (Dumpis et al. 2001, Suzuki 
et al. 2003, Kramvis et al. 2005, Vray et al. 2006, Kramvis \& Kew 2007, Hübschen et al. 2008). In our study, most of the HBV isolates belonged to genotype $\mathrm{E}$, which supports the idea that this genotype is the most prevalent genotype in west Africa (Bekondi et al. 2007, Kramvis \& Kew 2007).

Genotype A is found predominantly in southern, eastern and central Africa (Kramvis \& Kew 2007). Previous studies have suggested that isolates of genotype A have a longer natural history in Africa than the two other genotypes, D and E (Andernach et al. 2009a, b). Most of the African-derived genotype A isolates that have been sequenced to date belong to subgenotype A1, which is also the most prevalent subgenotype in Brazil (Araujo et al. 2004, Mello et al. 2007). Subgenotype A1 is thought to have been introduced into Brazil during the slave trade (Motta-Castro et al. 2008). Angola was one of the main suppliers of the slave trade and it is reasonable to think that subgenotype A1 was introduced into Brazil via Angola. Yet, only about $10 \%$ of the samples characterized here belonged to genotype A. Further studies with genotype A/subgenotype A1 from Brazil and Africa should be conducted to elucidate the origin of subgenotype A1, which is frequently detected in Brazilian individuals and rarely found in Luanda, the main port of the slave trade.

In conclusion, the present study showed that HBV is highly endemic in Luanda, with a predominance of genotype $\mathrm{E}$ and circulation of genotype A subgenotypes A1, A2 and A3. Further molecular characterization of complete HBV nucleotide sequences from Angola will allow the assessment of their genetic variability, possible molecular signatures and patterns of mutations and deletions. The possibility that recombination events have taken place between genotypes A and E for all HBV genes should also be considered.

\section{ACKNOWLEDGEMENTS}

To Francisco CA Mello, for helping with phylogenetic tree, and to Dr Christian Niel, for critical reading of the manuscript. DNA sequencing was performed by the Platform of Genomics and DNA Sequencing/PDTIS-PDTIS/Fiocruz.

\section{REFERENCES}

Abou MA, Eltahir YM, Ali AS 2009. Seroprevalence of hepatitis B virus and hepatitis $\mathrm{C}$ virus among blood donors in Nyala, South Dar Fur, Sudan. Virol J 6: 146.

Adoga MP, Banwat EB, Forbi JC, Nimzing L, Pam CR, Gyar SD, Agabi YA, Agwale SM 2009. Human immunodeficiency virus, hepatitis B virus and hepatitis C virus: sero-prevalence, co-infection and risk factors among prison inmates in Nasarawa State, Nigeria. J Infect Dev Ctries 3: 539-547.

Allain JP, Candotti D, Soldan K, Sarkodie F, Phelps B, Giachetti C, Shyamala V, Yeboah F, Anokwa M, Owusu-Ofori S, Opare-Sem $\mathrm{O} 2003$. The risk of hepatitis B virus infection by transfusion in Kumasi, Ghana. Blood 101: 2419-2425.

Andernach IE, Hübschen JM, Muller CP 2009a. Hepatitis B virus: the genotype E puzzle. Rev Med Virol 19: 231-240.

Andernach IE, Nolte C, Pape JW, Muller CP 2009b. Slave trade and hepatitis B virus genotypes and subgenotypes in Haiti and Africa. Emerg Infect Dis 15: 1222-1228.

André F 2000. Hepatitis B epidemiology in Asia, the Middle East and Africa. Vaccine 18 (Suppl. 1): S20-S22.
Araujo NM, Mello FC, Yoshida CF, Niel C, Gomes SA 2004. High proportion of subgroup A' (genotype A) among Brazilian isolates of Hepatitis B virus. Arch Virol 149: 1383-1395.

Batina A, Kabemba S, Malengela R 2007. Infectious markers among blood donors in Democratic Republic of Congo (DRC). Rev Med Brux 28: 145-149.

Bekondi C, Olinger CM, Boua N, Talarmin A, Muller CP, Le Faou A, Venard V 2007. Central African Republic is part of the West-African hepatitis B virus genotype E crescent. J Clin Virol 40: 31-37.

Botha JF, Ritchie MJ, Dusheiko GM, Mouton HW, Kew MC 1984. Hepatitis B virus carrier state in black children in Ovamboland: role of perinatal and horizontal infection. Lancet 1: 1210-1212.

Dumpis U, Holmes EC, Mendy M, Hill A, Thursz M, Hall A, Whittle $\mathrm{H}$, Karayiannis P 2001. Transmission of hepatitis B virus infection in Gambian families revealed by phylogenetic analysis. J Hepatol 35: 99-104.

François G, Dochez C, Mphahlele MJ, Burnett R, Van Hal G, Meheus A 2008. Hepatitis B vaccination in Africa: mission accomplished? South Afr J Epidemiol Infect 23: 24-28.

Hannoun C, Söderström A, Norkrans G, Lindh M 2005. Phylogeny of African complete genomes reveals a West African genotype A subtype of hepatitis B virus and relatedness between Somali and Asian A1 sequences. J Gen Virol 86: 2163-2167.

Harania RS, Karuru J, Nelson M, Stebbing J 2008. HIV, hepatitis B and hepatitis C coinfection in Kenya. AIDS 22: 1221-1222.

Hübschen JM, Andernach IE, Muller CP 2008. Hepatitis B virus genotype E variability in Africa. J Clin Virol 43: 376-380.

Hübschen JM, Mbah PO, Forbi JC, Otegbayo JA, Olinger CM, Charpentier E, Muller CP 2010. Detection of a new subgenotype of hepatitis B virus genotype A in Cameroon but not in neighbouring Nigeria. Clin Microbiol Infect, in press.

Kew MC 1996. Progress towards the comprehensive control of hepatitis B in Africa: a view from South Africa. Gut 38 (Suppl. 2): S31-S36.

Kramvis A, Kew MC 2007. Epidemiology of hepatitis B virus in Africa, its genotypes and clinical associations of genotypes. Hepatol Res 37: S9-S19.

Kramvis A, Restorp K, Norder H, Botha JF, Magnius LO, Kew MC 2005. Full genome analysis of hepatitis B virus genotype $E$ strains from South-Western Africa and Madagascar reveals low genetic variability. J Med Virol 77: 47-52.

Kurbanov F, Tanaka Y, Fujiwara K, Sugauchi F, Mbanya D, Zekeng L, Ndembi N, Ngansop C, Kaptue L, Miura T, Ido E, Hayami M, Ichimura H, Mizokami M 2005. A new subtype (subgenotype) Ac (A3) of hepatitis B virus and recombination between genotypes A and $\mathrm{E}$ in Cameroon. J Gen Virol 86: 2047-2056.

Makuwa M, Souquière S, Telfer P, Apetrei C, Vray M, Bedjabaga I, Mouinga-Ondeme A, Onanga R, Marx PA, Kazanji M, Roques P, Simon F 2006. Identification of hepatitis B virus subgenotype A3 in rural Gabon. J Med Virol 78: 1175-1184.

Martinson FE, Weigle KA, Royce RA, Weber DJ, Suchindran CM, Lemon SM 1998. Risk factors for horizontal transmission of hepatitis B virus in a rural district in Ghana. Am J Epidemiol 147: 478-487.

Meldal BH, Moula NM, Barnes IH, Boukef K, Allain JP 2009. A novel hepatitis B virus subgenotype D7 in Tunisian blood donors. J Gen Virol 90: 1622-1628.

Mello FC, Souto FJ, Nabuco LC, Villela-Nogueira CA, Coelho HS, Franz HC, Saraiva JC, Virgolino HA, Motta-Castro AR, Melo 
MM, Martins RM, Gomes SA 2007. Hepatitis B virus genotypes circulating in Brazil: molecular characterization of genotype $\mathrm{F}$ isolates. BMC Microbiol 7: 103.

Motta-Castro AR, Martins RM, Araujo NM, Niel C, Facholi GB, Lago BV, Mello FC, Gomes SA 2008. Molecular epidemiology of hepatitis B virus in an isolated Afro-Brazilian community. Arch Virol 153: 2197-2205.

Msuya SE, Mbizvo EM, Hussain A, Sam NE, Stray-Pedersen B 2006. Seroprevalence of hepatitis $B$ and $C$ viruses among women of childbearing age in Moshi Urban, Tanzania. East Afr Med J 83: 91-94.

Mulders MN, Venard V, Njayou M, Edorh AP, Bola Oyefolu AO, Kehinde MO, Muyembe Tamfum JJ, Nebie YK, Maiga I, Ammerlaan W, Fack F, Omilabu SA, Le Faou A, Muller CP 2004. Low genetic diversity despite hyperendemicity of hepatitis B virus genotype E throughout West Africa. J Infect Dis 190: 400-408.

Niel C, Moraes MT, Gaspar AM, Yoshida CF, Gomes SA 1994. Genetic diversity of hepatitis B virus strains isolated in Rio de Janeiro, Brazil. J Med Virol 44: 180-186.

Olinger CM, Jutavijittum P, Hübschen JM, Yousukh A, Samountry B, Thammavong T, Toriyama K, Muller CP 2008. Possible new hepatitis B virus genotype, southeast Asia. Emerg Infect Dis 14: 1777-1780.

Olinger CM, Venard V, Njayou M, Oyefolu AO, Maïga I, Kemp AJ, Omilabu SA, le Faou A, Muller CP 2006. Phylogenetic analysis of the precore/core gene of hepatitis B virus genotypes $\mathrm{E}$ and $\mathrm{A}$ in West Africa: new subtypes, mixed infections and recombinations. J Gen Virol 87: 1163-1173.

Oshitani H, Kasolo F, Tembo C, Mpabalwani M, Mizuta K, Luo N, Suzuki H, Numazaki Y 1995. Hepatitis B virus infection among pregnant women in Zambia. East Afr Med J 72: 813-815.

Palumbo E, Scotto G, Faleo G, Cibelli DC, Saracino A, Angarano G 2007. Prevalence of HBV-genotypes in immigrants affected by HBV-related chronic active hepatitis. Arq Gastroenterol 44: 54-57.

Pawlotsky JM, Bélec L, Grésenguet G, Deforges L, Bouvier M, Duval J, Dhumeaux D 1995. High prevalence of hepatitis B, C, and E markers in young sexually active adults from the Central African Republic. J Med Virol 46: 269-272.

Pirillo MF, Bassani L, Germinario EA, Mancini MG, Vyankandondera J, Okong P, Vella S, Guiliano M 2007. Seroprevalence of hepatitis $\mathrm{B}$ and $\mathrm{C}$ viruses among HIV-infected pregnant women in Uganda and Rwanda. J Med Virol 79: 1797-1801.

Pourkarim MR, Lemey P, Amini-Bavil-Olyaee S, Maes P, Van Ranst M 2010. Novel hepatitis B virus subgenotype A6 in African-Belgian patients. J Clin Virol 47: 93-96.

Schaefer S 2007. Hepatitis B virus taxonomy and hepatitis B virus genotypes. World J Gastroenterol 7: 14-21.

Sitnik R, Sette H Jr, Santana RA, Menezes LC, Graça CH, Dasto- li GT, Silbert S, Pinho JR 2007. Hepatitis B virus genotype E detected in Brazil in an African patient who is a frequent traveler. Braz J Med Biol Res 40: 1689-1692.

Steele AD, Bos P 1996. Hepatitis B and C virus infection in adult volunteers in Angola. S Afr Med J 86: 701-702.

Steele AD, Bos P, Joubert JJ, Bafort JM, Lecatsas G, Aspinall S 1995. Serologic markers for hepatitis B virus and hepatitis A virus in Bushmen in West Caprivi, Namibia. East Afr Med J 72: 30-32.

Strand RT, Franque-Ranque M, Bergström S, Weiland O 2003. Infectious aetiology of jaundice among pregnant women in Angola. Scand J Infect Dis 35: 401-403.

Sugauchi F, Orito E, Kato H, Suzuki S, Kawakita S, Sakamoto Y, Fukushima K, Akiba T, Yoshihara N, Ueda R, Mizokami M 2003. Genotype, serotype, and phylogenetic characterization of the complete genome sequence of hepatitis B virus isolates from Malawian chronic carriers of the virus. $J$ Med Virol 69: 33-40.

Sutcliffe S, Taha TE, Kumwenda NI, Taylor E, Liomba GN 2002. HIV-1 prevalence and herpes simplex virus 2, hepatitis $C$ virus, and hepatitis B virus infections among male workers at a sugar estate in Malawi. J Acquir Immune Defic Syndr 31: 90-97.

Suzuki S, Sugauchi F, Orito E, Kato H, Usuda S, Siransy L, Arita I, Sakamoto Y, Yoshihara N, El-Gohary A, Ueda R, Mizokami M 2003. Distribution of hepatitis B virus (HBV) genotypes among HBV carriers in the Cote d'Ivoire: complete genome sequence and phylogenetic relatedness of HBV genotype E. J Med Virol 69: 459-465.

Tamura K, Dudley J, Nei M, Kumar S 2007. MEGA4: Molecular Evolutionary Genetics Analysis (MEGA) software version 4.0. Mol Biol Evol 24: 1596-1599.

Tatematsu K, Tanaka Y, Kurbanov F, Sugauchi F, Mano S, Maeshiro T, Nakayoshi T, Wakuta M, Miyakawa Y, Mizokami M 2009. A genetic variant of hepatitis B virus divergent from known human and ape genotypes isolated from a Japanese patient and provisionally assigned to new genotype J. $J$ Virol 83: 10538-10547.

Uneke CJ, Ogbu O, Inyama PU, Anyanwu GI, Njoku MO, Idoko JH 2005. Prevalence of hepatitis-B surface antigen among blood donors and human immunodeficiency virus-infected patients in Jos, Nigeria. Mem Inst Oswaldo Cruz 100: 13-16.

Vray M, Debonne JM, Sire JM, Tran N, Chevalier B, Plantier JC, Fall F, Vernet G, Simon F, Mb PS 2006. Molecular epidemiology of hepatitis B in Dakar, Senegal. J Med Virol 78: 329-334.

WHO - World Health Organization 2004. Hepatitis B vaccines. Wkly Epidemiol Rec 79: 255-263.

Zhang SL, Han XB, Yue YF 1998. Relationship between HBV viremia level of pregnant women and intrauterine infection: neated PCR for detection of HBV DNA. World J Gastroenterol 4: 61-63. 